\title{
Why psychiatrists should watch films (or What has cinema ever done for psychiatry?)
}

\author{
Peter Byrne
}

Peter Byrne is a consultant liaison psychiatrist and film studies graduate. He devised and produced the short film 1 in 4 (available at www.rcpsych.ac.uk), which achieved a UK cinema distribution in 2001. His principal research interest is the stigma of mental health problems and the effects of prejudice and discrimination. He is Director of Public Education for the Royal College of Psychiatrists. Correspondence Dr Peter Byrne, Consultant Liaison Psychiatrist, Newham University Hospital, London E13 8SL, UK. Email: p.byrne@ucl.ac.uk

\begin{abstract}
SUMMARY
Cinema is at once a powerful medium, art, entertainment, an industry and an instrument of social change; psychiatrists should neither ignore nor censor it. Representations of psychiatrists are mixed but psychiatric treatments are rarely portrayed positively. In this article, five rules of movie psychiatry are proposed, supported by over 370 films. Commercial and artistic pressures reduce verisimilitude in fictional and factual films, although many are useful to advance understanding of phenomenology, shared history and social contexts in psychiatry. Acknowledging some negative representations, three areas are explored where cinema gets it mostly right: addictions, bereavement and personality disorder. Although there are excellent representations of psychosis on film, film-makers have more often portrayed it violently - ultimately demonising people as psychokillers in more than 100 films cited. When people with mental illness are stigmatised through stereotypes, examining unwelcome depictions can uncover important truths. Psychiatrists' engagement with film will ensure professional and artistic gains.
\end{abstract}

\section{DECLARATION OF INTEREST}

None.

Reg All right, but apart from the sani(John Cleese): tation, medicine, education, wine, public order, irrigation, roads, the fresh water system and public health, what have the Romans ever done for us?

Heckler: Brought peace?

Reg: Oh, peace... Shut up!

(Monty Python's Life of Brian 1979)

This review's longer title might run: 'Apart from the narratives, the visual pleasure, the innovations in form and content, the recognition, the stereotypes and the challenges, what has cinema ever done for psychiatry?' One of the many subversions in Monty Python's Life of Brian, banned on its initial release in Ireland and many other countries, is that Roman occupation also brought enduring benefits to a divided people. It strikes me when some psychiatrists complain about their unfavourable representations on film that cinema has given psychiatry and psychiatrists a platform they would not otherwise enjoy. Given the iron triangle of public anxiety and distrust of people with mental illness, an alienated tabloid press and government policies focused on populist measures (Cooper 2001), any media coverage that helps to engage that public is better than none. The worst response to 'bad' films would be a siege mentality/ asylum culture among mental health professionals. Would we and our patients really be better off if films with a theme of mental illness were censored or banned? Certainly, like the ancient Romans, some film-makers have been brutal in their actions, using a rigid doctrine to justify them, but it is better to engage with popular culture than to pretend we can operate outside it. My medical textbooks predicted manic patients with delusions of divinity, but I have seen more young people with psychosis who reference The Truman Show (1998) and The Matrix (1999) than higher powers. Many films perpetuate public perceptions that violence is a symptom of mental illness, but films depicting mental illness are not universally negative. No film has ever advocated reduced funding of mental health services: from factual films (Titticut Follies 1967, banned until 1991) and real-location films (One Flew Over the Cuckoo's Nest 1975) to modern releases (12 Monkeys 1995), they have shown substandard in-patient facilities. These films shine a useful light on institutional abuses and we must acknowledge our past failings when addressing some films' excesses.

\section{Caveat spectator}

Film is art but it is also a ruthless commercial enterprise, driven by populism and low cunning: 'follow the money' is the first rule of movie psychiatry (Box 1). Producers include any element to give the public what they think they want, just as actors in search of acting awards ignore a poorquality script to play someone with an intellectual disability or multiple personality disorder. We 
should not expect film-makers to be even-handed or knowledgeable in their choices of psychiatric representations. The key arguments here were first rehearsed by psychology professor and cineaste Franklin Fearing in 1946:

the attitude of the layman towards [amnesia] and other forms of abnormal behaviour is a curious mixture of fascination and horror which seems to increase in inverse ratio with the actual frequency of occurrence of these conditions... The writer or director will almost certainly present this material as merely spectacular or as a device which enables him to escape from an impasse in the plot... Certainly the systematic study of social psychology, anthropology, and allied social sciences wouldn't hurt Hollywood writers and directors, and it might make them a bit surer of their judgements as to what was psychologically right.

To these three observations is added the truism that film-makers learnt what they know about mental illness and its treatments at the cinema, not from books or in the clinic.

The second rule of cinema, artistic and commercial, is that film begets film: whether as inspiration for writers or an 'in' that helps the producer's pitch to the money men, every new genre film is based on what has gone before. Along with stereotypes (of doctors and patients), simplistic conceits of classic films depicting mental illness (Table 1) - for example, the repressed great dark secret that must be exposed to release the patient from misery - quickly became standard ingredients of the next generation of films. At its most extreme, the second rule allows for sequels and remakes, each more vacuously derivative than the last.

\section{Group work}

The opportunities to consume film have never been better (Table 2). From its early years as a fairground attraction, cinema was made to be consumed in groups. The modern book club (regular group meetings to discuss literature) becomes the culture club (film, play, music, exhibition). Excerpts or entire films are shown to medical undergraduates as 'cinemeducation' (e.g. Bhugra 2003; Alexander 2005). Table 1 lists 20 popular psychiatry films; they are all in the English language and are a mixture of comedy and drama. Representative of this genre, only one male psychiatrist breaks boundaries. Female movie psychiatrists always break professional rules with male patients and this has come to mean sexual liaisons. In the real world, where psychiatrists rarely sleep with their patients, men violate trust two to three times more often than women (Gharaibeh 2005). Films containing elements of mental illness require group viewing to place them in context and to counter similar
BOX 1 The five rules of movie psychiatry

1 Follow the money: film-making is a commercial enterprise and producers may include inaccurate representations in their films to 'give the public what they want'

2 Film begets film: every new film draws on previous films within the genre

3 Skewed distribution hides more films than censorship ever did

4 There are no mental health films, just mental illness ones

5 If it bleeds it leads: violence, injury and death often ensure prominence of a story in both news and film

filmic conceits. Gabbard \& Gabbard (1999) is the seminal work on screen psychiatrists, and Flowers $\&$ Frizler (2004) have compiled a list of psychotherapists in 5000 films from the first century of cinema. Before psychiatrists' fall from grace (Gabbard 1999), key questions posed by a movie psychiatrist brought gravitas to a commercial film. The professional could share 'deep thoughts' not unlike the marketing of 'psychological' thrillers. Inevitably, screenwriters adapted mental illness as source material (Table 1), but even within fantastical plots, these films have interesting things to say about modern psychiatry. In the timetravel fantasy 12 Monkeys, the chief of psychiatry instructs her residents about new admissions: 'evaluate, medicate and vacate'.

However, Table 1 is only the start of your journey: these are substantially hospital-based films and you need to get out more - into the community. Films about mental illness are niche films and usually make more revenue in 'sell through' sales (formerly video cassette but now DVD) than on brief cinematic release. The falling costs of film production have led to a burgeoning of releases, but hearing about them, let alone seeing them, is a challenge: the third rule is that skewed distribution hides more films than censorship ever did. As with previous innovations that presented a threat to film (television, video cassettes), the internet will feed the public's appetite for film. Take a group to the art house cinema (Table 2) a partial antidote to rule 3 (Box 1).

\section{A whole new world}

Any good film takes viewers to another world, holding their attention within the rules of that world to say something, anything. This is as true for science fiction, western and horror as it is for films about mental illness. At one level, Table 1 is all you need to start a psychiatry film club, but you would be missing out on an enormous canon of films. At the time of writing (the first 2 months of 2008), five outstanding films have taken us to the Japanese occupation of Shanghai (Lust, 


\begin{tabular}{|c|c|c|c|c|c|c|c|}
\hline Film (year) & Melodrama & Comedy & $\begin{array}{l}\text { Investigative } \\
\text { psychiatry }\end{array}$ & $\begin{array}{c}\text { Positive } \\
\text { representations of } \\
\text { psychiatrists }\end{array}$ & $\begin{array}{c}\text { Boundary } \\
\text { violations: } \\
\text { gender of } \\
\text { psychiatrist }\end{array}$ & $\begin{array}{l}\text { Abusive } \\
\text { psychiatry }\end{array}$ & $\begin{array}{c}\text { Unlawful } \\
\text { incarceration }\end{array}$ \\
\hline Blind Alley (1939) & $\checkmark$ & & $\checkmark$ & $\begin{array}{c}\checkmark \\
\text { (analyses criminal mind) }\end{array}$ & & & $\begin{array}{c}\checkmark \\
\text { (of psychiatrist) }\end{array}$ \\
\hline Spellbound(1945) & & & $\checkmark$ & $\begin{array}{c}\checkmark \\
\text { (cured by love: therapist) }\end{array}$ & $\begin{array}{c}\checkmark \\
\text { female }\end{array}$ & $\checkmark$ & \\
\hline The Snake Pit (1948) & $\checkmark$ & & & $\checkmark$ & & & \\
\hline The Cobweb (1955) & $\checkmark$ & & $\checkmark$ & $\checkmark$ & & & \\
\hline Fear Strikes Out 1957) & $\checkmark$ & & & $\begin{array}{c}\checkmark \\
\text { (cured by support plus ECT) }\end{array}$ & & & \\
\hline Shock Corridor (1963) & & & $\checkmark$ & & & $\checkmark$ & $\checkmark$ \\
\hline A Fine Madness (1966) & & $\checkmark$ & & & & $\checkmark$ & $\checkmark$ \\
\hline $\begin{array}{l}\text { One Flew Over the Cuckoo's } \\
\text { Nest (1975) }\end{array}$ & $\checkmark$ & $\checkmark$ & & & & $\checkmark$ & $\checkmark$ \\
\hline High Anxiety (1977) & & $\checkmark$ & $\checkmark$ & & & & \\
\hline Ordinary People (1980) & $\checkmark$ & & $\checkmark$ & $\begin{array}{c}\checkmark \\
\text { (improved by therapy) }\end{array}$ & & & \\
\hline Frances (1982) & $\checkmark$ & & & & & $\checkmark$ & $\checkmark$ \\
\hline House of Games (1987) & & & $\checkmark$ & $\begin{array}{c}\checkmark \\
\text { (analyses criminal mind) }\end{array}$ & $\begin{array}{c}\checkmark \\
\text { female }\end{array}$ & $\checkmark$ & \\
\hline Prince of Tides (1991) & $\checkmark$ & & $\checkmark$ & $\begin{array}{c}\checkmark \\
\text { (cured by love: therapist) }\end{array}$ & $\begin{array}{c}\checkmark \\
\text { female }\end{array}$ & & \\
\hline What About Bob? (1991) & & $\checkmark$ & & & & $\checkmark$ & $\checkmark$ \\
\hline 12 Monkeys (1995) & & & $\checkmark$ & & $\begin{array}{c}\checkmark \\
\text { female }\end{array}$ & & $\checkmark$ \\
\hline As Good as it Gets (1997) & & $\checkmark$ & $\begin{array}{c}\checkmark \\
\text { (road movie) }\end{array}$ & & & & \\
\hline Girl, Interrupted (1997) & $\checkmark$ & & & $\begin{array}{c}\checkmark \\
\text { (improved by therapy) }\end{array}$ & & & \\
\hline Antoine Fisher (2001) & $\checkmark$ & & $\checkmark$ & $\begin{array}{c}\checkmark \\
\text { (improved by therapy) }\end{array}$ & $\begin{array}{c}\checkmark \\
\text { male }\end{array}$ & & \\
\hline A Beautiful Mind (2001) & $\checkmark$ & & & $\begin{array}{c}\checkmark \\
\text { (cured by love: wife) }\end{array}$ & & & \\
\hline The Jacket (2005) & & & $\checkmark$ & & $\begin{array}{c}\checkmark \\
\text { female }\end{array}$ & $\checkmark$ & $\checkmark$ \\
\hline
\end{tabular}

Caution), a Texan manhunt (No Country for Old Men), locked-in syndrome (The Diving Bell and the Butterfly), teen pregnancy (Juno) and to the battle between capitalism and religion in pre-Depression America (There Will Be Blood). Films in which a mental health theme is a minor component stretch audiences beyond the confines of clinic-based psychiatry. We can't catch everything but as psychiatrists we should be familiar with what our patients and their families watch: astute clinicians explore people's preconceptions about psychiatric labels before imparting a new diagnosis. We all need cultural training and a major deficiency of the films in Table 1 is their lack of cultural variety - they are all US films. During the 'money shot', a stormy helicopter ride, in the French film Men, Women: A User's Manual (1996), Benoit (Bernard Tapie) remarks to his companion:

The Americans make little films with big budgets, the French make big films with small budgets. Why can't somebody combine the two?

The point here is that world cinema, independent 'small' films, documentaries, shorts and unconventional forms such as animation - all absent from Table 1 - can explore differences in personal stories, cultures, countries and genres. Taking Jack Hodgins' idea of 'lies that tell the truth' (Handcock 1979), film is fantasy. The global film village stretches beyond Hollywood. Colleagues have documented representations of 


\begin{tabular}{|c|c|}
\hline The medium & The message \\
\hline Television/satellite & $\begin{array}{l}\text { Watch live or record for private viewing on video, DVD or hard-disk drive (because films depicting mental illness are seldom mainstream, they } \\
\text { are often aired during afternoons or in the early hours) }\end{array}$ \\
\hline DVD & Buy (new or second hand) or rent (in person or from online DVD postal rental services) \\
\hline Internet & $\begin{array}{l}\text { Use generic and specialised search engines and websites (e.g. www.imdb.com) to identify films, genres and other information. Clips can be } \\
\text { found on YouTube or similar websites and short downloadable films can be viewed as live (e.g. www.15secondfilmfestival.com). Technology } \\
\text { will soon allow more ambitious legal downloads }\end{array}$ \\
\hline Print & $\begin{array}{l}\text { Academic articles and books (see References); journals, the best of which is the British Film Institute's monthly Sight and Sound, previewing } \\
\text { all UK releases as well as publishing academic standard review articles (www.bfi.org.uk); newspapers; magazines; and promotional materials } \\
\text { (marketing budgets have in some instances exceeded the cost of making the film, as I discussed in this journal in 2003) }\end{array}$ \\
\hline Radio & $\begin{array}{l}\text { Arts programmes (e.g. www.bbc.co.uk/radio4/arts/filmprogramme); Dr Mark Kermode's weekly peerless podcast of all new UK releases is at } \\
\text { www.bbc.co.uk/radio/podcasts/kermode }\end{array}$ \\
\hline Film club & $\begin{array}{l}\text { See text: clubs can be social, professional or as cinemeducation; choose films with positive aspects (artistic merit, well-known artists, } \\
\text { topicality, crossover appeal) in addition to those with a theme of mental illness }\end{array}$ \\
\hline Art house cinema & $\begin{array}{l}\text { An alternative to multiplex cinemas with their restricted repertoire (rule 3); good links to local film societies and groups who have the potential } \\
\text { to influence programming; retrospectives and special events to introduce audiences to film-makers both international and local }\end{array}$ \\
\hline Film festivals & $\begin{array}{l}\text { More than } 1000 \text { film festivals are listed at www.britfilms.com/festivals, many of which screen specialist films: only a minority of films that } \\
\text { receive a once-only festival screening are lost masterpieces }\end{array}$ \\
\hline
\end{tabular}

mental illness in Greek (Fountoulakis 1998) and Indian (Bhugra 2006) cinema. In watching world cinema, we must remember that just as filmmakers (mis)learnt psychiatry through film, there are limitations in learning about other cultures through film alone.

Rosen et al (1997) chart the rise of films from Australia and New Zealand that depict mental illness: beginning in 1994, they list 19 films in which central characters have become unwell. Collectively, these films have been dubbed the 'company of eccentrics' and represent a disproportionately high percentage of the region's cinema output. From a European perspective, this is the 'cinema of the outsider' who struggles to find his or her own voice. Many films (such as those discussed below, in 'When cinema gets it (mostly) right'), can be used to teach psychopathology and the wider effects of the mental illness label. Rosen et al conclude that the films are: 'encouraging, as are the messages of hope, resilience, rebellion, self-determination and triumph'. Not every aspect of these films is perfect. Their depiction of psychotropic medication has been examined in detail (Walter 1999). Positive messages (drugs taken under medical supervision are helpful when part of other therapies) are outweighed by actual negative (drugs can impair performance and are teratogenic) and inaccurate negative ones (high doses can anaesthetise from the neck up, non-adherence is always the patient's fault). Perhaps reflective of negative stereotypes of psychiatrists (see below), drugs are prescribed to control deviant behaviour, to impair enthusiasm (on the pretext that it is bipolar disorder) and in excessive doses by 'heavy-handed' clinicians (Walter 1999).

\section{History lessons}

For technical reasons and because of neglect, about $80 \%$ of silent films have been lost, with only stills and written descriptions remaining of them. Disproportionately more comedies and higher profile films have survived to the present day, but rare dramatic depictions stand out: Broken Blossoms (1919) and Page of Madness (1926) for psychopathy and psychosis, respectively. Flowers $\&$ Frizler (2004) identified 462 films from the silent era (1899-1929) that feature a psychotherapist, but only $73(15.8 \%)$ are available for viewing. Back then, role-play could cure mental illness: The Course of True Love (1905) and The Restoration (1909) are both silent films depicting talking therapy without a hint of irony. These films served as prototypes for the 'psychiatrist as detective' subgenre (Table 1), crystallised by Conflict (1945) in which a clever psychiatrist (Sidney Greenstreet) tricks the murderer (Humphrey Bogart) into implicating himself in his wife's murder.

Before censorship intervened - both ad hoc and self-censorship or formalised as the Hays Code in 1930 (www.classicmovies.org/articles/blhays code.htm) - many films depicted the horrors of drug and alcohol misuse (Tables $3 \& 4$ ). In A Drunkard's Reformation (1909), director D. W. Griffith uses shot-countershot (showing the person, then showing that person's point of view, to establish the reality of a scenario) and parallel editing (two separate but related events are edited together to heighten drama and invite other meanings). In his 
TABLE 3 Substance misuse in films

\begin{tabular}{|ll|}
\hline Substance misuse & Negative consequences \\
\hline Chinese Opium Den (1897) & Loss of control, addiction \\
\hline For His Son (1912) & $\begin{array}{l}\text { Victims of addiction to a (fictitious) cocaine-based } \\
\text { soft drink, 'Dopokoke' }\end{array}$ \\
\hline Opium (1919) & Tragic decline and fall \\
\hline Narcotic (1933; banned) & Decline and fall, addiction \\
\hline Man with the Golden Arm (1955) & Physical addiction, crime \\
\hline Bigger Than Life (1956) & Steroid-induced psychosis \\
\hline Valley of the Dolls (1967) & Decline and fall, suicide \\
\hline French Connection I/(1975) & Addicted cop, cold turkey \\
\hline Midnight Express (1978) & Prison, addiction, murder \\
\hline Christiane F(1981) & Dependence, prostitution \\
\hline Scarface (1983) & Violence, paranoia, murder \\
\hline Sid and Nancy (1986) & Decline and fall, suicide \\
\hline Clean and Sober(1988) & Dishonesty, loss of job \\
\hline Dead Ringers (1988) & Psychosis: homicide-suicide \\
\hline Drugstore Cowboy (1989) & Theft, death, betrayal \\
\hline Naked Lunch (1991) & Psychosis: kills his wife \\
\hline Rush (1991) & Undercover cop addicted \\
\hline Light Sleeper (1992) & III health, living death \\
\hline Bad Lieutenant(1992) & Corruption, exploits others \\
\hline Kids (1995) & Underage drugs and sex \\
\hline Trainspotting (1996) & Deaths, thefts, betrayals \\
\hline Boogie Nights (1997) & Illness, paranoia, murder \\
\hline Gridlock'd(1997) & Overdose, cycles of crime \\
\hline Requiem for a Dream (2000) & Prostitution, prison, illness \\
\hline Little Fish (2005) & Neglect of others, murder \\
\hline Walk the Line (2005) & Loss of status and health, misery \\
\hline Adam and Paul (2006) & \\
\hline Half Nelson (2006) & \\
\hline
\end{tabular}

reading of the film, Gunning (2004) argues that Griffith used these two technical innovations to create a moral contrast to soothe the authorities' moral panic in pre-Prohibition America. This film could also reflect its director's overdependence on alcohol in his life and in his films (the first seven films of Table 4): 'projection' has multiple meanings in film theory. Alcohol was also the first product to be advertised through film: Dewar's Scotch Whisky (1898). Merton (2007) sets out sophisticated comic representations of alcohol intoxication in silent comedy: the oft-copied Chaplin took the role of the drunk for himself realising that's where the laughs were - in films such as The Clinic (1917).

\section{Lambs of the silents}

Dr Dippy's Sanitarium (1906) initiated the eponymous comedic psychiatrist stereotype (Gabbard
1999) - his only treatment is pies for his patients - although humour is more usually directed (as here) at people with mental illness in 'lunatics on the loose' chase films from Off to Bloomingdale's Asylum (1901) to Who's Looney Now? (1914) to The Dream Team (1989).

More frequent than the Dippy archetype came the evil mesmerist who uses the dark art of hypnosis to gain advantage. Out of 42 surviving 'therapist' films from the first two decades of cinema, 10 feature a hypnotist (Flowers 2004). These films peaked with the German expressionist film The Cabinet of Dr Caligari (1919), inspiring Dr Mabuse the Gambler (1922), with six later reincarnations (sequels). Mabuse is the insane psychiatrist who commands a criminal empire; even after death, his ghost continues his dastardly work. Similar evil, mind-bending psychiatrists were unusual in talkies until reinvented as the ludicrous Dr Hannibal Lecter, who by Hannibal (2001) had acquired superhuman powers to stalk the land as a psychokiller. Given the second rule (films are derivative), copycat films turned on twists of convention (psychiatrist as patient, phoney psychiatrist, expert devoid of common sense, authority figure who can be corrupted), and Drs Dippy and Evil (Gabbard 1999) are merely flip sides of the idealised movie psychiatrist, Dr Wonderful. MacFarlane (2004) argued that contemporary excessively positive representations of psychiatrists and treatment benefits (11 films in Table 1) have unintended negative consequences for our patients: false hopes of a rapid and complete cure or expectations that therapists will bend the rules for them.

\section{Medical models}

As professionals, psychiatrists share many of the perceived core attributes of scientists:

- highly educated figures of authority, set aside from (or above) the rest of society

- employed directly by governments, making accountability seem remote

- their specialist subjects are difficult to understand and poorly explained

- use of empirical arguments drive a perception of reduced humanity.

In his study of scientists in cinema, Frayling (2005) identifies several themes:

- the price of professional success is relationship and personal failures

- genius, where there is narrow pursuit of a goal, approaches madness

- coercive powers over others are frequently misused ('for the greater good') 
- subjects reflect public concerns of the time: public dialogue about science began in film with poison gas, peaked with nuclear terrors and currently resides with human/genetic engineering.

Relevant to movie psychiatrists, "psychiatric fears' include hypnosis (see above), brainwashing (The Manchurian Candidate 1962, 2004; the Bourne trilogy 2002-07), unlawful incarceration (Table 1), torture-treatment (A Clockwork Orange 1972; Regeneration 1999; The Jacket 2005) and, combining all four, electroconvulsive therapy (ECT). The last has countless negative film representations (McDonald 2001) but these began positively with Autumn Leaves (1956) and Fear Strikes Out (1957). The only punitive psychiatric treatment, in A Beautiful Mind (2001), depicted insulin coma therapy; its psychiatric advisor was Professor Max Fink, an enthusiastic proponent of ECT. We can conclude that ECT will always get a rough cinematic ride or that we can potentially influence even powerful Hollywood studios: glass half-empty or glass half-full?

\section{But it's the truth even if it didn't happen}

The above subheading is the closing sentence of the first section of the novel One Flew Over the Cuckoo's Nest (Kesey 1962). The documentary Completely Cuckoo (Table 5) fails to recount the feature director Milos Forman's intention (as a Czech émigré) to depict the totalitarian state or the fact that real inmates of its asylum location were refused cameos in the film because they 'didn't look odd enough'. Just as modern fiction films borrow documentary form, documentary frequently crosses the line into fiction or exaggerates ('but it's almost true') to attract audience interest: rule 1 of film (follow the money). Epileptic Seizures 1-9 (1905), nine one-reel films, were in effect the first mental health documentaries and, in their treatment of their subjects as objects, a taste of things to come. Made by a physician with good intentions, they became circus.

\section{A question of ethics}

In the context of a recent resurgence of interest in documentary, with more achieving cinema release and the reward of higher-profile TV slots, there is a recent unwelcome trend of increasing boundary violations in mental health documentaries. During the Reel Madness Film Festival at the Institute of Contemporary Arts, London, in June 2003 a panel of documentrists all agreed that if they make films about mental illness, they expect the subjects to 'go off' during the filming period.

The fourth rule is that there are no films about mental health, just ones about mental illness.

\section{TABLE 4 Alcohol misuse in films}

\begin{tabular}{|ll|}
\hline Alcohol misuse & Negative consequences \\
\hline $\begin{array}{l}\text { A Drunkard's Reformation, What Drink } \\
\text { Did and The Lesson (all 1909), The } \\
\text { Converts (1910), The Crooked Road and His } \\
\text { Daughter (both 1911), The Struggle (1931) }\end{array}$ & $\begin{array}{l}\text { Depict economic consequences, abusive } \\
\text { relationships, neglect of family, dependence, ill } \\
\text { health, violence and death. }\end{array}$ \\
\hline The Craving (1918) aka Delirium & $\begin{array}{l}\text { Sober alcoholic cheated when he drinks again, } \\
\text { alcoholic hallucinosis }\end{array}$ \\
\hline Lost Weekend (1945) & Delirium tremens, status loss \\
\hline Country Girl (1954) & Archetypal alcoholic actor \\
\hline The Hustler (1961) & Self-loathing, despair, suicide \\
\hline Long Day's Journey into Night(1962) & Alcoholism sets up abusive relationships, wife's \\
& addiction \\
\hline Days of Wine and Roses (1962) & Loss of job and health \\
\hline Le Feu Follet (1963) & Broken relationships, suicide \\
\hline Who's Afraid of Virginia Woolf? (1966) & Husband and wife codependent on alcohol and each \\
& other \\
\hline Danger in the Skies (1979) & Alternative title: Drunk Pilot \\
\hline Withnail and I (1987) & Experiences darken with time \\
\hline Postcards from the Edge (1990) & Abusive maternal relationship \\
\hline Once Were Warriors (1994) & Domestic violence, poverty \\
\hline When a Man Loves a Woman (1994) & Neglect of children and marriage, family dynamics \\
\hline Leaving Las Vegas (1995) & Despair, physical illness, death \\
\hline Nixon (1995) & Paranoia, decline and fall \\
\hline Trees Lounge (1996) & Alcohol as a time- and life-waster \\
\hline Affliction (1997) & Damage to relationships, murder \\
\hline Nil By Mouth (1998) & Domestic violence, poverty \\
\hline My Name is Joe (1998) & Damage to relationships, suicide \\
\hline 28 Days (2000) & Denial, relationship problems \\
\hline There Will Be Blood (2008) & Anger, paranoia, murder \\
\hline & \\
\hline
\end{tabular}

There are exceptions to the exploitation of service users but sharp practices continue (Box 2; Stastny 1998).

Three recent documentaries pose ethical problems. The Bridge (2007) depicts suicide method in an excessive manner (something we know increases suicidal behaviour among viewers) and assumes consent from the dead to show their last moments and discuss their 'case'. It is more voyeurism and exploitation than exploration. Consent also dogs The Devil and Daniel Johnson (2006). Johnson is a highly influential singercomposer whose career was interrupted by episodes of severe mental illness. Public screening of The Devil and Daniel Johnson at the first Scottish Mental Health Arts Festival in 2007 (www. mhfestival.com) increased audiences' stigmatising attitudes towards mental ill health (N. Quinn, personal communication 2008). One challenge posed by the film is the response that psychiatrists might have if invited to comment on Johnson's behaviour in the completed film. In the absence of 


\begin{tabular}{|c|c|}
\hline Title & Description \\
\hline Epileptic Seizures 1-9(1905) & Real patients, brought out into bright sunlight and filmed until their seizures began. Ethics warning \\
\hline Witchcraft through the Ages (1922) & Contrasts the brutal treatments of women historically deemed possessed with enlightened psychiatric treatments \\
\hline Mechanics of the Brain (1925) & $\begin{array}{l}\text { Using combinations of live action (including real footage) and animation, and with the full cooperation of Pavlov, it } \\
\text { portrays his behavioural experiments }\end{array}$ \\
\hline Treasures III (1900-34) & Compilation of 48 films tackling social issues in American film \\
\hline Reefer Madness (1936, banned until 1947) & $\begin{array}{l}\text { Pseudodocumentary, opens with Dr Carroll (played by an actor), an educational psychologist who warns parents about } \\
\text { the evils of cannabis use (murder, suicide, psychosis) }\end{array}$ \\
\hline Let There Be Light (1946, banned until 1981) & $\begin{array}{l}\text { The US government funded this John Huston film, but banned it for } 35 \text { years for its realistic portrayals of } \\
\text { war-traumatised soldiers; both psychiatrists and the US army are represented positively throughout }\end{array}$ \\
\hline The Quiet One (1949) & Child therapist helps fictionalised patients from socially deprived New York \\
\hline Titticut Follies (1967) & Cinema verité visits a US asylum: inhumane, degrading treatments; no positive interventions. Ethics warning \\
\hline Revolution (1968) & Interviews about the positive and negative consequences of 'psycholytic' experiments with lysergic acid diethylamide \\
\hline Asylum (1972) & Fly-on-the-wall, unnarrated footage of RD Laing's medication-free therapeutic community in London \\
\hline Crumb (1994) & Insight into the unconventional lives of cartoonist Robert Crumb, his brother Charles, other family and friends \\
\hline Completely Cuckoo (1997) & Interesting if incomplete retelling of the making of the 1975 film One Flew Over the Cuckoo's Nest \\
\hline The Alcohol Years (2000) & Award-winning documentary exploring writer Carol Morley's alcohol misuse and her lost years \\
\hline Daughter of Suicide (2000) & A personal investigation into the circumstances and the consequences of a mother's suicide \\
\hline Cinemania (2002) & $\begin{array}{l}\text { Five 'movie buffs' wander New York to see as many films (best versions and in the correct aspect ratios) as possible- } \\
\text { up to } 2000 \text { a year each; they are invited to give their reasons and they comment on this film }\end{array}$ \\
\hline Capturing the Friedmans (2003) & $\begin{array}{l}\text { A unique documentary and the product of a real family's practice of filming and destroying itself: multiple accusations } \\
\text { of child sexual abuse against the father, including incest, divide the family further }\end{array}$ \\
\hline Shake Hands with the Devil (2004) & $\begin{array}{l}\text { The story of Rwandan genocide as told by (UN-appointed) General Roméo Dallaire through the prism of international } \\
\text { apathy, societal trauma and his own subsequent alcohol misuse }\end{array}$ \\
\hline I for India (2005) & Home movies and new footage of an immigrant doctor's experiences torn between the UK and 'home' \\
\hline $\operatorname{Thin}(2005)$ & The stories and personal experiences of four Florida-based women who have eating disorders \\
\hline Shock (2007) & $\begin{array}{l}\text { Balanced depiction of ECT; useful alongside public-friendly factual information: e.g. www.rcpsych.ac.uk/ } \\
\text { mentalhealthinformation.aspx }\end{array}$ \\
\hline
\end{tabular}

his consent for our comments about him (we hope he consented to the film) or any direct assessment of him, this would seem as unethical as discussing Britney Spears or other unmet celebrities in the media spotlight. The account of unconventional therapy in The Doctor Who Hears Voices (2008) shines a harsh ethical light on the therapist (he takes many risks and at one point invites his patient to his holiday home), whereas the film itself is honest and ethical.

\section{More fact than faction}

In addition to the 20 documentaries listed in Table 5 , documentaries from the National Film Board of Canada, the BBC and Channel 4's Animated Minds are honourable exceptions to exploitation and misrepresentation. Penn et al (2003) showed a schizophrenia documentary and found that although it made audience attitudes more benign, it did not change their opinions about violence or their intentions about future contact with people with schizophrenia. Domino (1983) found no effect of a documentary shown to 146 students but 'substantial' negative effects of One Flew Over the Cuckoo’s Nest. My direct involvement as programme consultant to Horizon's two-part programme How mad are you? (2008), about the stigma of psychiatric labels, was a positive experience. Although the programme achieved high ratings and good reviews, its effects on audience attitudes has not been formally evaluated.

\section{When cinema gets it (mostly) right}

Cape (2003) criticises films that depict alcohol and drug misuse as stigmatising, dividing them into four stereotypes: the tragic hero, rebellious free spirit, demonic/homicidal maniac and humorous/ comedic user. There are certainly recognisable types (rule 2: film begets film) but taken together, films about addiction (Tables $3 \quad \& \quad 4$ ), with occasional lapses, are brutally honest about the consequences (if not the causes) of addiction. Many films that initially trivialise substance misuse (Le Feu Follet 1963; Easy Rider 1969; 
Withnail and I 1987; Trainspotting 1996) proceed to depict serious consequences for the user. It would be a challenge to name an occupation not depicted on screen for which alcohol misuse leads to lost opportunities, career decline and worse. Some films depicting drug misuse (e.g. Requiem for a Dream 2000) could not be more harrowing about the terrible consequences of addiction even if made by health professionals. This is true of the messages in Trainspotting (dehumanising capitalist drug subculture that degrades its members), which seem conservative alongside those of mental health professionals (Byrne 1997).

One unintended consequence of censorship is the gap in films showing the horrors of addiction in the early talkies (Tables $3 \& 4$ ). Symptoms of drug misuse are highly filmic, as are the delusions and hallucinations of psychosis (first column, Table 6). Many of these films go beyond symptoms and signs to contextualise the experience of psychosis. The Madness of King George (1994) depicted highs and lows, whereas Mr Jones (1993) excised depression to allow more room for its star's exuberant behaviour in getting the girl (his psychiatrist of course).

There are three categories of 'psychosis film': rules 1-4 (Box 1) have moved the public perception of the disorder from the first into the second column of Table 6 . The first column approaches verisimilitude, the second is about spectacle. Like Chekhov's gun (the gun seen in the First Act that must be fired in the Final Act; http://en.wikipedia. org/wiki/Chekhov's_gun), film-makers have focused not just on the $10 \%$ of people with psychosis who may become violent during their illness, but on the tiny proportion who kill (second column, Table 6). Either film-makers became bored with psychosis without homicide or they needed conflict, in its extreme forms, to heighten drama. Added to these, major actors and directors (James Cagney, Jack Nicholson, Stanley Kubrick, Robert De Niro, Martin Scorsese) influenced subsequent films: see rule 2 (film begets film).

\section{Good $/$ Bad = Ugly}

Another line was crossed with the seminal Psycho (1960), by itself the originator of the psychokiller genre (third column, Table 6). This film conflates violence with mental illness, as it does schizophrenia with multiple personality disorder: both conceits are nailed down with the movie psychiatrist's epilogue explaining Norman's murderous acts. Equating 'split personality' with Jekyll/Hyde (that is, good/bad) initiated the dichotomy that continues to drive the public's worst perceptions of mental illness. Convention
B0X 2 Two perspectives of documentary film-making
Arnold Shapiro: rule 3 for documentary film-makers, 'Be responsible'

'Just as doctors have oaths and guidelines they are obliged to follow, nonfiction producers should maintain the highest standards of accuracy and factual storytelling. We owe that to our audience because when they watch our films they are being educated, forming opinions, and being influenced by what we present. We owe our audience accuracy, honesty, and truthfulness.' (Shapiro 1998)

Janey Antoniou: experiences of a service user with schizophrenia as 'subject' (posted on www.rethink.org)

'For Violent Voices, a ten minute documentary, I was interviewed by a researcher who had associated schizophrenia with violence but changed his mind (and the mind of the producer/director) after talking to me. The filming took two days, and additional footage was shot by my husband when I was ill, something I'd agreed to in advance. I was in hospital the day, and I got a spontaneous round of applause from everyone in the ward. The director and I exchanged Christmas cards for years afterwards.

For Edge of Madness, a long documentary featuring four people with schizophrenia, I ended up doing things with which I was uncomfortable because they had bought me dinner, or had spent time with me. I had got myself in a position where I didn't feel I could say no. Parts of it make me cringe, and there are bits that I feel deeply ashamed about because they give the wrong impression about mental health problems, especially schizophrenia. When I wrote to the people who made it afterwards I got no reply and they never sent some of my pictures and poems back to me. It is difficult at the beginning of a film project to see where it's going to go but I think if I was asked again and if I started to feel uncomfortable about a scene I would try to discuss it before the filming started.' when it came out, they sent me flowers on

makes the killer a quiet man 'who wouldn't even hurt a fly' (Psycho) and who 'flips' from good to bad, suddenly and inexplicably. When portraying the extremes of bad behaviour, how else can amoral 'psychos' express themselves other than by violence and homicide? This is given life (and reincarnation) as the psychokiller, who kills initially for revenge, then for pleasure (Byrne 1998). Frequently more franchise than series, the many psychokiller films (Table 6) are so excessive we can easily dismiss them, but we cannot dismiss 'realistic' films linking psychosis and violence (second column, Table 6).

A variation on Chekhov's gun, rule 5 is 'if it bleeds it leads'. This is the maxim of television news editors, who will always move up a story featuring injury and death, as examined in the pages of this journal (Byrne 2003). We are stuck with this - film audiences enjoy watching violence - and the madman who walks among us is as good a villain as any. This rule pulls decent film-makers from the first to the second column in Table 6 and exploitative ones from the second to the third. Violent psychosis is as strong in film folklore as are hard-drinking cops and hookers with hearts of gold, and even government ministers don't know the difference between psychopathic and psychotic, as I have noted before (Byrne 2003). 
TABLE 6 Psychosis and its very, very distant cousins (twice removed, violently) on film

\begin{tabular}{|c|c|c|}
\hline Psychosis (mostly accurate portrayal) & Violent psychosis (mostly homicide) & Psychokiller films (more than 100) \\
\hline Page of Madness (1926) & $M(1931)$ & Jekyll and Hyde (1920): more than 20 versions \\
\hline The Snake Pit (1948) & White Heat(1949) & Psycho (1960): four sequels, one remake (1997) \\
\hline The Caine Mutiny (1954) & Peeping Tom (1960) & Asyluma (1972) \\
\hline Bigger than Life (1956) & Lolita (1962; remade 1997) & Frenzy (1972) \\
\hline David and Lisa (1962) & Repulsion (1965) & Madhouse (1974) \\
\hline Dr Strangelove (1964) & Images (1972) & The Texas Chainsaw Massacre (1974): five remakes \\
\hline Persona (1966) & Taxi Driver(1975) & Schizo (1976) \\
\hline Eraserhead (1976) & Magic (1978) & Halloween (1978): seven sequels, one remake \\
\hline Network (1976) & The Ninth Configuration (1979) & Dressed To Killa (1980) \\
\hline I Never Promised You a Rose Garden (1977) & The Shining (1980) & Friday the Thirteenth (1980): eleven sequels \\
\hline The Bell Jar (1979) & Contagion (1987) & A Nightmare on Elm Street (1984): seven sequels \\
\hline Birdy (1984) & Full Metal Jacket (1987) & The Hitcher (1986): one sequel, one remake \\
\hline Benny and Joon (1991) & Dead Ringers (1988) & The Stepfather (1987): two sequels, two remakes \\
\hline The Fisher King (1991): induced by trauma & $\begin{array}{l}\text { Misery (1990): character with psychosis is violent, } \\
\text { but is killed by her male victim }\end{array}$ & Child's Play (1988): four sequels \\
\hline Mr Jones (1993) & Bad Boy Bubby (1993) & Maniac Cop (1988): two sequels \\
\hline The Madness of King George (1994) & Clean, Shaven (1993) & Psycho Cop (1988): one sequel \\
\hline Out of Darkness (1994) & Deadly Advice (1993) & Cape Fear (1991), itself a remake \\
\hline Angel Baby (1995) & Kalifornia (1993) & Silence of the Lambs ${ }^{\mathrm{a}}$ (1991): six sequels/prequel/other \\
\hline Lillian's Story (1995) & Heavenly Creatures (1994) & Candyman (1992): two sequels \\
\hline Cosi (1996) & Butterfly Kiss (1995) & Raising Cain ${ }^{\mathrm{a}}$ (1992) \\
\hline Mad Love (1996) & Seven (1996) & Single White Female (1992) \\
\hline Shine (1996) & The Butcher Boy (1997) & Copycat (1995) \\
\hline $\operatorname{Pi}(1997)$ & The Cell (2000) & Scream (1996): two sequels \\
\hline Some Voices (2000) & Disco Pigs (2002) & American Perfekta (1997) \\
\hline Kira's Reason (2001) & Spider (2002) & I Know What You Did Last Summer (1997): two sequels \\
\hline A Beautiful Mind (2001) & Asylum (2005) & Saw (2004): four sequels \\
\hline I'm a Cyborg (2006): early homicidal fantasies & Murder Inside of Me (2005) & Wolf Creek (2005) \\
\hline Michael Clayton (2007) & Keane (2006) & Grindhouse (2007): Death Proof and three trailers \\
\hline
\end{tabular}

apsychiatrist/doctor as the psychokiller.

\section{Good grief}

The opening narrator in Field of Dreams (1989) sets up his own world:

I'm 36 years old, I love my family, I'm about to become a father. Until I'd heard the Voice, I'd never done a crazy thing in my whole life.

The intense yearning and hallucinations of acute grief have spawned a subgenre (third column, Table 7) of bereavement films. At 20 films, the list is short but contains highly successful films, crossing mainstream genres with only three horror films. Were this list to include more horror, dozens of zombie films, including their comic variants, 'zom coms', would lengthen it. Despite a perception that cinema denies death (bullet-proof heroes, high body counts, the gift of eternal youth to actors from make-up and lighting departments), all of the 76 films in Table 7 portray the aftermath of a death. Some therapists advocate watching these films as part of psychotherapy but evidence is unlikely to justify prescribing films for individual patients: many could overwhelm.

Although Field of Dreams is not strictly a film about mental illness, aspects of its fantasy are useful to understand normal grief. There are various markers of pathological grief (phobic avoidance of people/places related to the deceased; extreme guilt and anger; total lack of grief; overidealisation of the deceased; physical illness; and recurring nightmares of the deceased) and it is also defined by longevity. Although fewer films depict this consistently, these films (third column, Table 7) have profound insights into the process, whereas others (first and second columns) portray some aspects of pathological grief. 


\begin{tabular}{|c|c|c|c|}
\hline $\begin{array}{l}\text { Bereavement from a child's } \\
\text { perspective }\end{array}$ & Grieving adults & $\begin{array}{l}\text { Depiction of visual hallucinations } \\
\text { (of the dead) }\end{array}$ & Pathological grief \\
\hline The Champ (1931, 1979) & Four Horsemen of the Apocalypse (1921) & A Guy Named Joe (1943) & Rebecca (1940) \\
\hline Citizen Kane (1940) & Goodbye Mr Chips (1939) & A Matter of Life and Death (1946) & Vertigo (1958) \\
\hline Bambi(1942) & Sentimental Journey (1946) & The Boy with Green Hair (1948) & La Chambre Verte(1978) \\
\hline The Cowboys (1972) & Oliver's Story (1978) & Hamlet (1948) & Bed of Roses (1995) \\
\hline Paper Moon (1973) & Don't Look Now (1973) & Back from the Dead (1957) & Mrs Brown (1997) \\
\hline Ordinary People (1980) & Barry Lyndon (1975) & Solaris (1972) & Under the Skin (1997) \\
\hline Le Fracture du Myocarde (1990) & The Big Chill (1983) & The Empire Strikes Back (1980) & \multirow{2}{*}{$\begin{array}{l}\text { Three Burials of Melquiades } \\
\text { Estrada(2005) }\end{array}$} \\
\hline My Girl (1991) & Terms of Endearment (1983) & An American Werewolf in London (1981) & \\
\hline The Cement Garden (1992) & Accidental Tourist (1988) & Blood Simple (1984) & Wristcutters. A Love Story (2006) \\
\hline Le Jeune Werther (1992) & Everybody's Fine (1990) & Star Trek III. The Search for Spock (1984) & \multirow{2}{*}{$\begin{array}{l}\text { Before the Devil Knows You're Dead } \\
\text { (2008) }\end{array}$} \\
\hline Shadowlands (1993) & Life and Nothing But (1990) & Always (1985) & \\
\hline Sleepless in Seattle (1993) & The Doctor(1991) & $D a(1988)$ & \\
\hline Untamed Heart (1993) & Peter's Friends (1992) & Field of Dreams (1989) & \\
\hline Elisa (1994) & My Life (1993) & Ghost(1990) & \\
\hline The Lion King (1994) & Shadowlands (1993) & Truly, Madly, Deeply (1991) & \\
\hline Bogus (1996) & Exotica (1994) & Under the Sands (2000) & \\
\hline Fly Away Home (1996) & The Crossing Guard (1995) & The Others (2001) & \\
\hline The Butcher Boy (1997) & The Sweet Hereafter (1997) & Solaris (2002) & \\
\hline The Sixth Sense (1999) & Good Will Hunting (1998) & Birth (2004) & \\
\hline Al: Artificial Intelligence (2004) & In the Bedroom (2001) & The Orphanage (2007) & \\
\hline In America (2003) & The Son's Room (2001) & & \\
\hline Soba (2004) & About Schmidt (2003) & & \\
\hline \multirow[t]{2}{*}{ Wilbur Wants to Kill Himself(2004) } & Jindabyne (2007) & & \\
\hline & In the Valley of Elah (2008) & & \\
\hline
\end{tabular}

\section{Traits of mind}

Representations of people with personality disorders are too numerous to list here. Borderline and dissocial personality disorders are excellently portrayed by Evelyn and Joey in Play Misty for Me (1971) and Goodfellas (1990) respectively. Although people with personality disorders and personality difficulties make for challenging patients, their dilemmas and behaviours make for great cinema: rule 4 (illness over health) and rule 5 (if it bleeds it leads). The challenge might be to list powerful dramatic films in which characters do not have personality difficulties: without conflict and misunderstanding there would be no drama. Referring back to Table 1, the absence of personality difficulties from the mainstream movie psychiatry genre is striking. Only three films feature a central character with a personality disorder. McMurphy's psychopathy in One Flew Over the Cuckoo's Nest and Bob Wiley's dependent personality disorder in What About $B o b$ ? are each stand-out performances, and a cinematic gift to teachers. Of equal merit, Girl Interrupted showcases borderline and dissocial personality disorder in two highly regarded central performances: Winona Ryder and Angelina Jolie. This film is exceptional in that it breaks the rule that, as with psychosis (Table 6), most representations of these two common personality disorders are of violence: rule 5 (if it bleeds...)

How long might it take to agree the personality profile of the eponymous Citizen Kane (1940)? The film showcases childhood loss, grief, narcissism, selective recall, alcohol misuse, attempted suicide and probable alexithymia in Kane himself. As with psychosis, violence - especially in the context of the two personality disorders mentioned above - dominates these representations: rule 5 again.

\section{The return of the repressed}

The films in Table 1 expend relatively little effort on determining which mental illness the patient has, and less on understanding wider societal reactions to their illness. Patients are passive foils: even as investigators, they go along with stronger characters in the narrative. In The Flame Within (1936), the female psychiatrist is advised to choose marriage and family over her career, and in Lady 
in the Dark (1944) a male psychiatrist advises Liza (Ginger Rogers) that she needs a man who will dominate her. During psychiatry's 'Golden Age' (1930s to 1960s) of positive representation of professionals, female deviance became an object of psychiatric discourse, played out as a subgenre (Walker 1993).

Worse than in documentaries, people with mental illness in fiction films are either victims in melodrama (Table 1) or objects of comedy. As a rule, their only empowerment is as violent agents but this stereotype contributes most to stigma.

Contemporary film theory has borrowed even more from psychiatry than have film-makers (a story for another day) but it provides the means of deconstructing films. It seems unlikely that movie psychiatry will deviate from its current path unless, as professionals, we move beyond consumption to commenting on film. In engaging with media commentators or film-makers, think of yourself not as a 'Christian thrown to the lions' but as a dissenting voice who can assimilate ideas into ancient Roman culture - a project ultimately achieved by Christianity. Another thing the Romans did for us.

\section{References}

Alexander M, Lenahan P, Pavlov A, et al (2005) Cinemeducation: A Comprehensive Guide to Using Film in Medical Education. Radcliffe Publishing.

Bhugra D (2003) Teaching psychiatry through cinema. Psychiatric Bulletin; 27: 429-30.

Bhugra D (2006) Mad Tales from Bollywood. Portrayal of Mental IIIness in Conventional Hindi Cinema. Psychology Press.

Byrne P (1997) Trainspotting and the depiction of addiction. Psychiatric Bulletin; 21: 173-5

Byrne P (1998) Fall and rise of the movie 'psychokiller'. Psychiatric Bulletin; 22: 174-6.

Byrne P (2003) Psychiatry and the media. Advances in Psychiatric Treatment; 9: 135-42.

Cape GS (2003) Addiction, stigma and movies. Acta Psychiatrica Scandinavica; 107: 163-9.
Cooper B (2001) Public health psychiatry in today's Europe. Scope and limitations. Social Psychiatry and Psychiatric Epidemiology; 36 : $169-76$

Domino G (1983) Impact of the film 'One Flew Over the Cuckoo's Nest' on attitudes towards mental illness. Psychological Reports; 53: 179-82.

Fearing F (1946) Psychology and the films. Hollywood Quarterly; 2: $118-21$.

Flowers J, Frizler P (2004) Psychotherapists on Film, 1899-1999 (2 volumes). McFarland \& Co.

Fountoulakis K, Kogiopoulos K, Nimatoudis I, et al (1998) The concept of mental disorder in Greek cinema. Acta Psychiatrica Scandinavica; 98: $338-40$

Frayling C (2005) Mad, Bad and Dangerous. The Scientist and the Cinema. Reaktion Books.

Gabbard G0, Gabbard K (1999) Psychiatry and the Cinema (2nd edn). American Psychiatric Press.

Gharaibeh NM (2005) The psychiatrist's image in commercially available American movies. Acta Psychiatrica Scandinavica; 111: 316-9.

Gunning T (2004) From the opium den to the theatre of morality. Moral discourse and the film process in early American cinema. In The Silent Cinema Reader (eds L Grievson and P Krämer): 145-54. Routledge.

Handcock G (1979) An interview with Jack Hodgins. Canadian Fiction Magazine; XXXII/XXXIII: 62

Kesey K (1962) One Flew Over the Cuckoo's Nest. Methuen.

MacFarlane S (2004) Antoine Fisher. How dangerous is 'Dr Wonderful'? Australasian Psychiatry; 12: 176-8.

McDonald A, Waters G (2001) The portrayal of ECT in American movies. Journal of ECT; 17 : 264-74

Merton P (2007) Silent Comedy. Random House.

Penn DL, Chamberlin C, Mueser KT (2003) The effects of a documentary film about schizophrenia on psychiatric stigma. Schizophrenia Bulletin; 29: $383-91$

Rosen A, Walter G, Politis T, et al (1997) From shunned to shining. Doctors, madness and psychiatry in Australian and New Zealand cinema. Medical Journal of Australia; 167: 640-7.

Shapiro A (1998) Ten golden rules. In The Search for Reality. The Art of Documentary Filmmaking (ed M Tobias): 259-70. Michael Wiese.

Stastny P (1998) From exploitation to self-reflection. Representing persons with psychiatric disabilities in documentary film. Literature and Medicine: 17: 68-90.

Walker J (1993) Couching Resistance. Women, Film and Psychoanalysis. University of Minnesota Press.

Walter G, Rosen A (1999) Sweet medicine or a bitter pill to swallow? The depiction of psychotropic medication in recent movies from Australia and New Zealand. Australian Journal of Psychopharmacology; 9: 61-4. 